\title{
Colonization of freshly deposited barite and silica sediments by marine microorganisms in a laboratory flume flow
}

\author{
Robert H. Findlay ${ }^{1}$, Stacy L. Kim ${ }^{2}$, Cheryl Ann Butman ${ }^{3}$ \\ ${ }^{1}$ Department of Biochemistry, Microbiology and Molecular Biology, and Center for Marine Studies, Darling Center, \\ University of Maine, Walpole, Maine 04573, USA \\ ${ }^{2}$ Biology Department, Woods Hole Oceanographic Institution, Woods Hole, Massachusetts 02543, USA \\ ${ }^{3}$ Applied Ocean Physics and Engineering Department, Woods Hole Oceanographic Institution, Woods Hole, \\ Massachusetts 02543 , USA
}

\begin{abstract}
The biomass and structure of microbial communities colonizing barite freshly deposited onto natural marine mud was investigated in a laboratory flume. Modern biochemical methods based on the lipid content of microbial cells were used to quantify microbial colonization. The experiment involved the following 3 treatments: (1) fresh barite deposited onto the surface of a natural muddy sediment; (2) fresh silica (utilized as a colonization control) also deposited onto natural mud; and (3) the muddy sediment itself. The treatments were placed in an open-channel flow with $10 \mu \mathrm{m}$ filtered sea water and sampled every other day for $16 \mathrm{~d}$. The flow was set at a shear velocity $\left(u\right.$.) of $0.30 \mathrm{~cm} \mathrm{~s}^{-1}$, less than the critical $u$. to initiate sediment motion of these particles. After $48 \mathrm{~h}$, the barite and silica treatments contained approximately 60 times less microbial biomass than the natural mud. Little change in microbial biomass was observed in the barite and silica treatments until $13 \mathrm{~d}$ of incubation when microbial biomass began to increase. The carbon content of the fresh barite and silica treatments was 60 to 570 times less than in the natural mud and this lower carbon content is the likely proximal cause of the lower microbial biomass. The structure of microbial communities was analyzed after $13 \mathrm{~d}$ of incubation. Despite the large difference in total biomass, microbial communities in the natural mud and barite treatments were similar in structure. In the silica treatment, however, community structure was highly variable and dissimilar to the natural mud community. The community in flowing sea water was more similar to communities in natural mud and barite than in silica. These results suggest that natural marine sediments receiving inputs of barite can be expected, given sufficient time, to develop microbial communities similar in structure and possibly biomass to those found in ambient sediments.
\end{abstract}

\section{INTRODUCTION}

Colonization of fresh surfaces by bacteria is an important first step in the development of mature biofilms in aquatic environments. Under laboratory conditions the rate of biomass accumulation has been described with a stochastic model based on availability of cells in the bulk flow, shear stress at the surface, and cell-surface interactions (Escher \& Characklis 1988). If cell growth at the surface is included, these models are accurate for the first $10 \mathrm{~h}$ of the colonization process. Similar models have been applied to mixed populations under natural conditions (Characklis \& Marshall 1990). As biofilms mature, usually over a period of days to weeks, community complexity increases. However, repeated sampling of mature biofilms, in either natural or model laboratory systems, has not been accornplished without disturbing the integrity of the system (Keevil 1989). Hence, our understanding of subsequent (to the initial $10 \mathrm{~h}$ ) stages of biofilm development and maturation is far less complete (Kogure 1989). Understanding microbial colonization processes in sediments, with their added complexity and increased difficulty of direct observation, has proven even more elusive.

This study was designed to quantify, under realistic flow conditions, initial colonization (over $15 \mathrm{~d}$ ) of thin layers of barite and silica deposited onto a natural marine mud. Barite $\left(94\right.$ to $96 \% \mathrm{BaSO}_{4}$; Cantelmo et al. 
1979) was chosen because of its potential environmental effects (discussed later) and silica $\left(\mathrm{SiO}_{2}\right)$ was chosen as a colonization control for potential inhibitory effects of barite and because it is a major component of natural sediments. This is the first colonization study of marine sediments conducted under steady, unidirectional, turbulent flow in a laboratory flume so that colonization rates can be evaluated within the context of natural field flows. In addition to the importance of this work for evaluating effects of barite deposition in marine systems, this study provides much-needed information on rates and community composition of microbes initially colonizing freshly deposited, abiotic sediments. Developing an understanding of colonization processes for relatively simple, but realistic cases, such as the one studied here, provides the foundation for an understanding of colonization processes in more complex, natural systems.

\section{Microbial colonization of sediments}

Factors influencing the distribution of microbes in sediments include sediment grain size and shape (Meadows \& Anderson 1967, Weise \& Rheinheimer 1978, Nickels et al. 1981, Hoppe 1984, Mayer et al. 1985), carbon content (Cammen 1982, DeFlaun \& Mayer 1983, Yamamoto \& Lopez 1985), fluid flux to the bed (Thistle et al. 1984, Eckman 1985), sediment disturbance (Wainright 1987. Findlay et al. 1990a) and animal-microbe interactions (Federle et al. 1983, Aller \& Yingst 1985, Dobbs \& Guckert 1988, Reichardt 1988, Findlay et al. 1990b). Of these, the first 3 are most likely to influence microbial colonization of freshly deposited, abiotic sediments. Bacterial abundance is inversely related to sediment grain size - smaller sediment grains have more bacteria because of their greater surface area per unit volume (Zobell 1938, Hargrave 1972, Dale 1974, Rublee \& Dornseif 1978 , DeFlaun \& Mayer 1983, Yamamoto \& Lopez 1985) and positively related to carbon content of sediments (Cammen 1982, DeFlaun \& Mayer 1983, Yamamoto \& Lopez 1985). The latter relationship is complex, however, because carbon content tends to increase with increasing sediment surface area (Deflaun \& Mayer 1983). In addition, several authors (Hargrave 1972, DeFlaun \& Mayer 1983) have noted that bacteria rarely colonize sediment grains $\leq 10 \mu \mathrm{m}$ in diameter and that the addition of clay minerals to sediments decreases bacterial abundances (DeFlaun \& Mayer 1983, Yamamoto \& Lopez 1985). It can generally be expected, however, that bacteria will colonize sediments with smaller grain sizes and higher carbon contents more rapidly than larger grains and sediments with less carbon.
Local variations in fluid (and thus also nutrient) flux to the substratum are known to affect local distributions of bacterial biomass (Thistle et al. 1984) and local rates of bacterial colonization of fresh substratum at the sediment-water interface (Eckman 1985), as well as altering community metabolic status (Thistle et al. 1984). These results and the demonstrated importance of boundary shear stress to colonization in 2-dimensional systems (e.g. flat plates; reviews of Baier 1984, Escher \& Characklis 1990), indicate that any study of sediment colonization must be conducted using realistic, controlled and well-defined flow regimes so that results can be placed within a field context.

\section{Barite deposition and potential benthic ecological effects}

During exploratory and production drilling for of $f$ shore oil, thousands of tons of drill cuttings and spent drilling muds are deposited around the drill site (e.g. Menzie 1982). Drilling muds are mixtures used to transport cuttings to the surface, to prevent blowout by balancing formation pressures, and to cool, lubricate and support the drill bit and drill pipe. Drilling muds are recovered from the cuttings and, if possible, reused. Cuttings are discharged continually, whereas the spent drilling mud is dumped, en masse, at the end of the drilling process. Depending on the flow regime and water depth at the drill site, accumulations of cuttings may exceed $6 \mathrm{~m}$, and of drilling muds $6 \mathrm{~cm}$ in height (National Research Council 1983); cutting piles are recognizable within hundreds of meters, and drilling muds are detectable within kilometers of a drill site (Boesch \& Rabalais 1987).

The primary constituent of drilling muds is barite, a mined ore that contains 94 to $96 \% \mathrm{BaSO}_{4}$ (Cantelmo et al. 1979). Trace metal concentrations in barite ore are generally lower than in marine sediments and are in insoluble metal sulfide or granular form, with low bioavailability (Neff 1987). Studies of the effects of spent drilling muds released on the continental shelf have focused on the minor, more toxic constituents of drilling muds, such as petroleum products and biocides (review of Neff 1987. Macdonald et al. 1988). Studies on pelagic animals have shown, for the most part, only minimal effects; the chemicals were not toxic at the concentrations tested (Neff 1987). Sublethal, behavioral changes have been noted over short periods of time, but these changes may be due to the increased suspended sediment load rather than to toxicity (Carls \& Rice 1984). Some drilling fluids with diesel oil additives, however, have demonstrated toxicity for pelagic organisms as a result of high concentrations of aromatic hydrocarbons (Neff 1987). 
Benthic organisms are likely to be more susceptible to drilling-mud effects, however, because $>90 \%$ of the discharged solids settle directly to the bottom (National Research Council 1983). By the time the drilling muds reach the bottom, concentrations of potential toxins are well below lethal levels and laboratory toxicity experiments indicate minimal toxic effects on sessile organisms (National Research Council 1983, Neff 1987). Field experiments on the effects on macro- and meiofaunal colonization of drilling muds (Tagatz et al. 1978) or barite (Tagatz \& Tobia 1978, Cantelmo et al. 1979) mixed in with or placed on top of azoic sands indicated depressed abundances of some species and depressed species richness, but the cause(s) for these changes is(are) unknown. Other than these studies, specific effects of physical burial by drilling muds on benthic habitat and communities has not been explored. Whereas soft-bottom communities can recover, often rapidly, from benthic disturbances, studies have focussed largely on natural or mimics of natural physical disturbances (e.g. Thistle 1981 Woodin 1981, VanBlaricom 1982), and on enrichmenttype disturbances (e.g. Grassle et al. 1985, Gooday \& Turley 1990, Snelgrove et al. in press).

Studies on effects of large input of exotic, abiotic particles (such as the barite contained in drilling muds) to the marine environment would be enlightening both from an environmental and an ecological perspective, because deposition of such particles represents an experimental manipulation to natural marine sediments. Barite has a grain-size distribution of $14.4 \%$ clay $(<4 \mu \mathrm{m}), 81.8 \%$ silt $(4$ to $63 \mu \mathrm{m}$ ) and $3.8 \%$ sand $\left(\geq 63 \mu \mathrm{m}\right.$ ) and a mass density of $4.50 \mathrm{~g} \mathrm{~cm}^{-3}$, almost twice that of quartz $\left(2.65 \mathrm{~g} \mathrm{~cm}^{-3}\right)$, a major component of most natural marine sediments. Because of its density, the critical erosion velocity of a barite particle is higher than that of a similarly-sized quartz sediment particle (Shields 1936, as reported in Miller et al. 1977), such that silt-sized barite particles would tend to remain on the seafloor in flow regimes that erode natural silt, and likewise, clay-sized barite particles would tend to remain on the seafloor in flow regimes that erode natural clays (e.g. Drake et al. 1992). Thus, a potential net effect on benthic habitat of barite deposition would be the formation of a surface sediment layer with a smaller grain-size distribution than the natural sediments for a given flow regime. As a particle, then, barite presents an opportunity to explore the effects of grain size versus flow regime on the distribution of benthic organisms (Jumars \& Nowell 1984). First, however, biologically relevant properties of barite particles (e.g. particle surface area, organic carbon accumulation rates, and microbial colonization and community composition) must be characterized to permit the design and interpretation of meaningful ecological experiments.
This study is a first step toward defining the potential for barite to behave like natural sedimentary particles in the marine environment by comparing microbial colonization of a thin layer of barite to colonization of a thin layer of silica, both deposited onto a natural mud. Because a common criticism of laboratory studies on drilling-mud effects is that they do not attempt to mimic realistic field conditions (National Research Council 1983), we conducted this study in a relatively slow, steady, unidirectional, turbulent flow over a hydraulically smooth bed. This flow is at the low end of the range of flows occurring at typical drilling sites on the continental shelf (e.g. Butman 1987, Lyne et al. 1990, Drake et al. 1992). Sediment treatments were chosen to maintain (as closely as possible) similar grain-size distributions. Microbial biomass and community structure were determined using biochemical methodology based on the membrane components of all cells (Findlay et al. 1989, Vestal \& White 1989). This paper reports changes in microbial biomass over time in all 3 substrates and evaluates microbial community composition after $13 \mathrm{~d}$. These results are placed within the context of microbial colonization processes and the potential ecological effects of releasing barite into the marine environment during exploratory and production drilling activities.

\section{MATERIALS AND METHODS}

Materials. Solid-phase extraction columns (silicic acid and C18) were obtained from J. T. Baker, Inc., Phillipsburg, NJ, USA. Glass-distilled solvents (Burdick and Jackson, Muskegon, WS, or Mallinkrodt, St. Louis, MO, USA) were used. Derivatizing reagents and authentic standards were purchased from Pierce Chemical Co., Rockford, IL, and Aldrich Chemical Co., St. Louis, MO, USA. Fused silica Capillary GLC Durabond columns (DB-1) were supplied by $J \& W$ Laboratories Inc., Rancho Cordova, CA, USA. All glassware was washed with non-phosphate detergent, rinsed 5 times with tap water and 10 times with Megapure ${ }^{\circledast}$ deionized water, air dried and rinsed with dichloromethane just prior to use.

Sediment preparation and analyses. Dry barite (API Standard, M I Drilling Fluids) and silica (Sil-co-sil 60, US Silica Company) were pre-treated prior to introduction into the flume by wetting minimally (addition of ca 1 l) with $0.2 \mu \mathrm{m}$ filtered (Nuclepore) sea water. Bacterial abundance in the filtered water was determined by direct counts. Two $2 \mathrm{ml}$ samples were fixed in $0.04 \mathrm{ml} 25 \%$ glutaraldehyde and stained with $0.2 \mathrm{ml}$ acridine orange $(0.1 \%$ in $0.02 \mathrm{M}$ tris buffer, $\mathrm{pH} 7.5)$, filtered over $0.2 \mu \mathrm{m}$ Nuclepore filters stained with Irgalan Black, and viewed under an epifluorescence 
microscope at $3000 \times$ (oil immersion). Twenty-five fields (of $2 \times 10^{4}$ fields filter ${ }^{-1}$ ) were haphazardly selected and the number of bacteria counted. The filtered sea water contained 7 to $8 \times 10^{3}$ bacteria $\mathrm{ml}^{-1}$. Fresh muddy sediment was collected using a Van Veen grab at Stn $\mathrm{R}\left(41^{\circ} 29.3^{\prime} \mathrm{N}, 70^{\circ} 53.4^{\prime} \mathrm{W}_{i} 70 \mathrm{~m}\right.$ depth) in Buzzards Bay, Massachusetts, USA (see Sanders 1958 for detailed description of the site). The top $1 \mathrm{~cm}$ of sediment was scraped of and pushed through a $300 \mu \mathrm{m}$ sieve without using water. Sieved Buzzards Bay sediment (subsequently referred to as 'natural mud') was stored at $4{ }^{\circ} \mathrm{C}$ until use (ca $6 \mathrm{~h}$ ).

Percentages of organic carbon, hydrogen and nitrogen (CHN) of each sediment (barite, silica and natural mud) were determined using a Perkin-Elmer Model 240 Elemental Analyzer on carbonate-free sediments (sulfurous acid wash; Gibbs 1977). Specific surface area analysis was performed on the sediments after removal of organic matter by boiling in hydrogen peroxide. Surface area values were directly measured with the 1 point BET nitrogen sorption procedure (Brunauer et al. 1938) using a Quantachrome Monosorb (Quantachrome Corp., Syosset, NY, USA) and the protocol outlined in Mayer et al. (1988). Grain-size distributions were determined using a Coulter Counter; all 3 sediment types were first disaggregated by sonification.

Laboratory flume. The colonization experiments were conducted in a recirculating, temperature-controlled, flowing sea water channel - the 17-Meter Flume at the Coastal Research Laboratory (Woods Hole, Massachusetts, USA), described in detail in Butman \& Chapman (1989). The flume channel is $17.3 \mathrm{~m}$ long by $0.6 \mathrm{~m}$ wide by $0.3 \mathrm{~m}$ deep and is covered with 14 removable panels of $2 \mathrm{~cm}$ thick polyvinylchloride (PVC) that serve as a false bottom. The water is recirculated by a centrifugal pump and temperature is controlled to $\pm 0.5^{\circ} \mathrm{C}$. The flume is constructed of non-toxic materials: fiberglass, glass, plastics and high-grade stainless steel. Flow velocities are measured with a 2-axis, forward-scatter, laser-Doppler velocimeter (LDV) sampling at $32 \mathrm{~Hz}$. Flume calibrations comparing profiles of mean velocity, Reynolds stress and turbulence intensity with previous theoretical and empirical results have shown good agreement (Trowbridge et al. 1989).

Experiments were conducted in a $50 \times 50 \times 1 \mathrm{~cm}$ deep region (referred to as the 'test section') of the bed located $12 \mathrm{~m}$ from the entrance. The test section was cut out of 1 of the false-bottom panels and sediments were filled flush with the surrounding surface. The flume was filled to 10.5 (Expt 1) or 10.0 (Expt 2) cm depth with $10 \mu \mathrm{m}$ filtered sea water and maintained at $21^{\circ} \mathrm{C}$ in the dark (except for sampling and occasional checks on water level and flow). The flow was set at $5 \mathrm{~cm} \mathrm{~s}^{-1}$ ( $7 \mathrm{~cm}$ above the bottom); boundary shear velocity $(u \cdot)$ was below the threshold for initial motion of all 3 sediments, as determined by visual observations. Using the LDV, a detailed velocity profile (13 points, 6 min averages per point) was taken at the end of Expt 2 (see below) and $u$. calculated using the 'profile technique' (e.g. Gross \& Nowell 1983). Using 9 points between 0.6 and $3 \mathrm{~cm}$ above the bed (log-layer region determined graphically) resulted in a $u$. of $0.30 \mathrm{~cm} \mathrm{~s}^{-1}\left( \pm 0.033 \mathrm{~cm} \mathrm{~s}^{-1}, 95 \%\right.$ confidence interval; $\left.\mathrm{r}^{2}=0.9845\right)$. This is a hydraulically smooth, turbulent flow, as indicated by a roughness Reynolds number (Re. $=d u . / \nu$, where $d=$ grain diameter and $\nu=$ kinematic fluid viscosity) of less than 3.5 (e.g. Nowell \& Jumars 1984).

Colonization experiments. Expt 1: The first experiment involved 2 sediment treatments, barite and silica. Wetted barite and silica suspensions were allowed to settle for $18 \mathrm{~h}$, the water decanted off, and a $25 \mathrm{~cm}$ wide by $50 \mathrm{~cm}$ long sirip of each sediment was packed into the test section; treatment locations were determined haphazardly. The sediment sampling regime was carefully designed to minimize potential bias due to upstream-downstream and cross-stream location effects (e.g. Fig. 1), although such effects were not expected because of the highly 1 -dimensional flow in this flume (Trowbridge et al. 1989). Each sediment treatment was divided into 3 columns parallel to the flow direction and at each sampling time, 1 subsample $\left(1 \mathrm{~cm}^{3} ; 19 \mathrm{~mm}\right.$ diameter cores inserted to $\left.1 \mathrm{~cm}\right)$ was taken from within each column. In addition, the upstream-downstream location of each of the 3 pairs

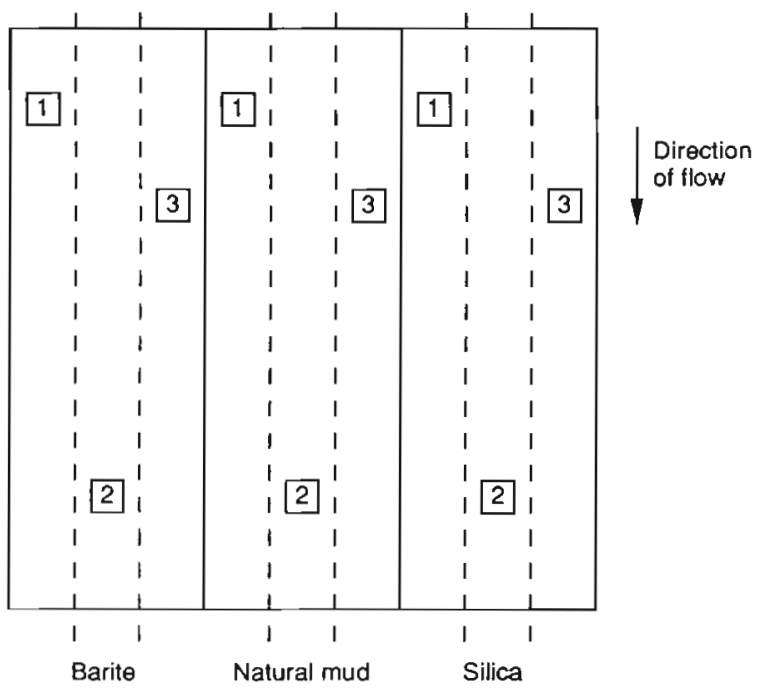

Fig. 1. Sediment sampling regime for Expt 2 to minimize bias due to potential upstream-downstream or cross-stream location. effects (see text). Numbers represent 3 subsamples taken at each point in time. A similar sampling regime was used for Expt 1, but there were only 2 sediment treatments (barite and silica) 
( 1 from each treatment) of subsamples was determined from a random-number table. These subsamples were taken every other day for $8 \mathrm{~d}$. Sediment samples were immediately placed in a methanol-dichloromethanewater extraction mixture, and stored at $-10^{\circ} \mathrm{C}$ until analysis for total phospholipid phosphate. After each sampling, a PVC plug was inserted into the 'hole' caused by sampling to minimize local flow disturbances due to irregular bed roughness. On 5 occasions, power outages caused the flume to stop (for maximum of $3 \mathrm{~h}$ at a time), but the sediment remained aerobic and fully water-saturated for the duration of the experiment.

Expt 2: Because negligible microbial colonization was detected in Expt 1 (see 'Results'), fresh barite and silica sediments were layered over natural mud in Expt 2, the mud serving as a potential source of organic carbon and bacteria within close proximity of the surface sediments. In addition, a strip of pure natural mud was added as a third sediment treatment; this resulted in three $16.7 \mathrm{~cm}$ wide by $50 \mathrm{~cm}$ long strips of sediment (Fig. 1). Wetted barite and silica sediments were allowed to settle for $30 \mathrm{~h}$ at $4{ }^{\circ} \mathrm{C}$ and the excess water decanted off. The test section was filled with natural mud to a depth of $8 \mathrm{~mm}$ and divided into 3 equal sections, using clear plastic dividers, parallel to the flow direction. A $2 \mathrm{~mm}$ layer of either barite, silica or mud was added on top of each section; treatment locations were determined haphazardly. Measurements $(n=3)$ of the depth of the barite or silica layers at the end of the experiment confirmed that they were, in fact, $2 \mathrm{~mm}$ deep, on average (mean $=2.0, \mathrm{SD}=0$ for silica; mean $=2.0, \mathrm{SD}=0.82$ for barite). Subsamples of the surface sediments of each treatment were taken by sliding a thin plastic ruler under the top $2 \mathrm{~mm}$ of sediment and carefully lifting it away; the sampling design is shown Fig. 1 and was described previously. Replacement plugs were not used because $2 \mathrm{~mm}$ roughness was not expected to substantially change the local flow regime. Subsamples (ca $1 \mathrm{~cm}^{3}$ ) for microbial biomass and $\mathrm{CHN}$ were taken immediately after filling of the test section, $1 \mathrm{~d}$ later, and every other day for $15 \mathrm{~d}$, except for Day 13, when larger subsamples (ca $6 \mathrm{~cm}^{3}$ ) were taken so that microbial community structure also could be analyzed. In addition, two 2 l sea water samples were siphoned from the water column over the test section prior to sediment sampling on Day 13. They were analyzed for both total microbial biomass and microbial community structure.

Sediment samples for lipid analysis were immediately placed in a methanol-dichloromethane-water extraction mixture, and stored at $-10^{\circ} \mathrm{C}$ until analysis for total phospholipid phosphate. Samples for CHN analysis were immediately dried at $60^{\circ} \mathrm{C}$. Sea water samples were filtered through $0.2 \mu \mathrm{m}$. FP Vericel filters
(Gelman \#66477) that were placed in a lipid extraction mixture and stored at $-10^{\circ} \mathrm{C}$ until analysis for total phospholipid phosphate and phospholipid fatty acids. Unused filters were extracted to serve as filter blanks.

Analyses of microbial biomass and community structure. Total biomass was determined for sediment samples from Days 0 and 8 in Expt 1 and the sea water samples from Day 13 and all sediment samples, except Days 3,7 and 11 for the natural mud in Expt 2. Total microbial biomass was determined using a biochemical assay based on quantification of total phospholipid present within a sediment. Lipids were recovered by dichloromethane-methanol extraction and total phospholipid phosphate determined by the method of Findlay et al. (1989). This method can detect ca $0.1 \mathrm{nM}$ of phospholipid phosphate or about $1 \times 10^{6}$ microbial cells. We used the phospholipid to carbon conversion factor developed by Findlay et al. (1989), although less conservative conversion factors have been proposed (e.g. Brinch-Iversen \& King 1990). Extracted sediments were recovered and dry weights determined. The volume (in $\mathrm{cm}^{3}$ ) of sediment extracted was then calculated using experimentally determined regression lines.

The Day 13 sediment and sea water samples in Expt 2 were also analyzed for microbial community structure. Subsequent to total biomass determinations, phospholipids were purified by silicic acid column chromatography. The fatty acids were recovered as methyl esters after basic methanolysis. Fatty acid methyl esters (FAME) were purified by reverse-phase column chromatography utilizing SPE C-18 columns and an acetonitrile-water liquid phase. FAMEs were separated and quantified by gas chromatography (Varian 3400, fitted with split/splitless injector, flame ionization detector and a non-polar, $60 \mathrm{~m}$, fused silica capillary column) and identified by coelution with known standards. FAME identifications were subsequently confirmed by mass spectral identification.

Statistical analyses. All statistical analyses were performed using Systat (version 3.2, copyright 1988, Systat, Inc.) and a Macintosh SE or were calculated using the algorithms of Ott (1988) and Myers (1979), Excel 2.2a and a Macintosh IIsi. If significant heteroscedasticity of variance was found, the data were $(\vee x+1)$ transformed and the analyses repeated. Data from Expt 1 were not analyzed statistically because microbial abundances were so low.

Because of the exploratory nature of this study, neither experiment was replicated. In addition, because there was only a single strip of each sediment treatment in each experiment, we could not statistically test for a treatment effect independent of a location effect. This experimental design, using single, wide strips of each sediment treatment rather than a 
large number of small patches of each treatment randomly distributed within the test section, was selected for biological reasons - to minimize the amount of lateral 'border' of each treatment, where 2 treatments are in contact and could potential affect bacterial colonization of each other. Although there is no reason to expect cross-stream location within the test section to affect bacterial colonization of a given sediment treatment, especially given that flow characteristics are bilaterally symmetrical in this flume (Trowbridge et al. 1989), we have refrained from statistically contrasting microbial biomass between sediment types because the treatments are pseudoreplicated in this experimental design. We did, however, statistically analyze changes in microbial biomass over time within a given treatment. Sampling within each test strip was randomized with respect to its leading or upstream edge and was fixed with regard to cross-stream location. Thus, the data were analyzed with a randomized blocks design ANOVA, with no replication, and cross-stream location serving as the blocking factor. This design does allow a limited (within treatment) test for location effects. A significant block effect would indicate systematic cross-stream variance; otherwise, the assumption of uniform crossstream flow would be supported.

The microbial communities from each sediment type and the overlying water were compared on Day 13 of Expt 2 using a 1-way ANOVA with substratum type (natural mud, barite, silica and sea water) as the treatment effect. This analysis assumes that there are no significant location effects (i.e. the pseudo-replication problem mentioned above), an assumption that is supported by the bilateral symmetry of the flume flow and the lack of significant block effects in the microbial biomass analysis described above (see Table 2 and 'Results'). Twenty-nine individual phospholipid fatty acids (PLFAs) were recovered from the samples and the percentage of each fatty acid in the total concentration (commonly referred to as relative abundance) was tested for a treatment effect. Because there was no compelling reason to exclude an individual PLFA from further analysis, 29 individual ANOVAs were conducted. All data were $\ln (x+1)$ transformed prior to statistical analysis. This analysis assumes abundances of the individual PLFAs in the sediments are independent. If the $\alpha$ level for rejecting the null hypothesis in each individual comparison is set at 0.05, then the analysis has an error rate per family (EF; the probability that there are 1 or more Type I errors among the 29 ANOVAs; e.g. Myers 1979) of 0.77 . We thus selected an $\alpha$ level per comparison of 0.02 to reduce the EF to 0.46. Although this family error rate is still high, the probability of generating more than 2 Type I errors in the 29 ANOVAs is only 0.02. This represents a useful compromise allowing some control of EF while moderating the increase in probability of Type II errors.

\section{RESULTS}

\section{Microbial biomass}

In Expt 1, $1 \mathrm{~cm}^{3}$ of both barite and silica contained less than $1 \times 10^{6}$ bacteria, the limit of detection for the total phospholipid phosphate method, on both Days 0 and 8 . Hence, we altered the experimental design for Expt 2 to include fresh natural sediments which could supply additional organic carbon to the system and the experiment duration was extended to ca $2 \mathrm{wk}$.

In Expt 2, the barite and silica, after $30 \mathrm{~h}$ of pretreatment with $0.2 \mu \mathrm{m}$ filtered sea water, contained ca 60 times less microbial biomass than similarly pretreated natural mud (Table 1). Microbial biomass peaked $1 \mathrm{~d}$ later in the natural mud and then generally declined with time. In contrast, microbial biomass in barite and silica remained relatively unchanged until 13 and $15 \mathrm{~d}$ after the start of the experiment.

Analysis of variance of individual treatments indicated that there were significant differences with time in the natural mud and barite treatments and that there were no significant block effects for all 3 sediment types (Table 2). The changes in microbial biomass in the natural mud were quite similar to those reported by Findlay et al. (1990a) for sand sediments following sieving. In the present study, $24 \mathrm{~h}$ after sediment pretreatment (sieving and storing for $\mathrm{ca} 6 \mathrm{~h}$ at $4^{\circ} \mathrm{C}$ ),

Table 1 Colonization of fresh barite and silica by marine microorganisms at time (d) after exposure to sea water in Expt 2. All data given as mean $\pm 1 S D, n=3$, except silica, Day 2 where $n=1$. nd: not done

\begin{tabular}{|c|c|c|c|c|c|c|c|c|c|}
\hline \multirow{2}{*}{$\begin{array}{r}\text { Treatment } \\
\text { Day: }\end{array}$} & \multicolumn{9}{|c|}{$\begin{array}{c}\text { Microbial biomass } \\
\text { (nmol phospholipid phosphate } \mathrm{cc}^{-1} \text { sediment) }\end{array}$} \\
\hline & 0 & 1 & 3 & 5 & 7 & 9 & 11 & 13 & 15 \\
\hline Natural mud & $57.23 \pm 6.23$ & $65.06 \pm 2.44$ & nd & $49.89 \pm 90.76$ & nd & $44.74 \pm 0.77$ & nd & $36.70 \pm 0.74$ & $45.44 \pm 4.15$ \\
\hline Barite & $1.01 \pm 0.19$ & $1.84 \pm 0.76$ & $0.58 \pm 0.34$ & $1.45 \pm 0.85$ & $1.00 \pm 0.47$ & $0.97 \pm 0.56$ & $0.77 \pm 0.25$ & $4.49 \pm 2.45$ & $2.42 \pm 0.96$ \\
\hline Silica & $0.73 \pm 0.39$ & 1.19 & $1.14 \pm 1.56$ & $0.75 \pm 0.09$ & $0.58 \pm 0.48$ & $1.65 \pm 1.87$ & $0.68 \pm 0.30$ & $2.25 \pm 126$ & $3.32 \pm 2.18$ \\
\hline
\end{tabular}


Table 2. Analysis of variance (see text) for changes in microbial biomass of natural mud, barite and silica over time in Expt 2

\begin{tabular}{|c|c|c|c|c|c|}
\hline Source & $d f$ & SS & $F$ & $\mathrm{p}$ & $\mathrm{SNK}^{\mathrm{d}}$ \\
\hline \multicolumn{6}{|c|}{ Natural mud } \\
\hline Time & 5 & 7.496 & 25.405 & 0.001 & 13915501 \\
\hline Block & 2 & 0.008 & 0.067 & $>0.25$ & \\
\hline Error & 10 & 0.590 & & & \\
\hline \multicolumn{6}{|l|}{ Barite } \\
\hline Time & 8 & 0.299 & 5.091 & 0.005 & 311970511513 \\
\hline Block & 2 & 0.003 & 0.189 & $>0.25$ & \\
\hline Error & 16 & 0.118 & & & \\
\hline \multicolumn{6}{|l|}{ Silica } \\
\hline Time & 7 & 0.315 & 2.063 & $>0.10$ & na \\
\hline Block & 2 & 0.088 & 2.016 & $>0.10$ & \\
\hline Error & 14 & 0.306 & & & \\
\hline \multicolumn{6}{|c|}{$\begin{array}{l}\text { 'Student-Newman-Keuls (SNK) test for multiple comparisons of } \\
\text { means calculated using the algorithms in Ott (1988). Means are } \\
\text { ordered from smallest to largest and those connected by a line are } \\
\text { not significantly different ( } \mathrm{p}<0.05 \text { ). Numbers indicate days from } \\
\text { start of experiment; na: not applicable }\end{array}$} \\
\hline
\end{tabular}

microbial biomass peaked. This was followed by a general decline in microbial biomass over time. The lowest biomass was observed on Day 13 of the experiment. In contrast, microbial biomass in barite remained relatively unchanged until 13 and 15 d after the start of the experiment when biomass significantly increased. Microbial biomass in the silica treatment showed a similar trend, though these changes were not significant. These results indicate that microbial biomass began to increase in both silica and barite approximately 2 wk after exposure to flowing sea water and natural sediments.

\section{Microbial community composition}

We analyzed sediments and samples of the overlying water collected on Day 13 for microbial community structure using a phospholipid fatty acid analysis. Cluster analysis of the fatty acid profiles from the Day 13 samples indicated that the samples fell into 4 groups (Fig. 2). The largest cluster consisted of the natural mud and barite subsamples. The second cluster consisted of the 2 overlying water subsamples. The third cluster contained 2 (of 3 ) of the silica subsamples. The final cluster had 1 element (a single silica subsample) and was, by far, the most unique. In general, this analysis indicates that the microbial community present in natural mud and barite were most similar. The microbial community in the overlying water was moderately similar to the natural mud and barite communities. In contrast, the microbial community in silica was most variable and unique.
Subsequent to cluster analysis, ANOVAs were performed on the percentages of the individual fatty acids to determine the specific nature of the differences between treatments (Table 3 ). Thirteen of the twentynine fatty acids showed significant treatment effects $(p<0.02)$. Multiple comparison of means (Student-Newman-Keuls test, SNKtest, $p<0.05$ ) indicated several interesting differences between treatments. These were: (1) natural mud contained several trace fatty acids $(16: 4 w 1,16: 2,18: 1 w 5)$ not found in any of the other treatments; (2) the overlying water contained significantly less of the fatty acids 22:5w6, 22:6w3, i17:0, 10Me16:0 and i16:0 and significantly more of the fatty acids 15:0 and $\mathrm{a} 17: 0$; and (3) the silica sediments contained significantly more of the fatty acids 22:5w6, 18:0, cy17:0 and i17:0 and significantly less of the fatty acids $18: 1 \mathrm{w} 7$, a17:0 and 15:0.

\section{Sediment analyses}

The organic carbon content of the sediment treatments on Days 0, 13 and 15 of Expt 2 (Table 4) indicates that fresh barite and silica contained very little organic carbon compared to the natural mud. The carbon content of the natural mud was ca $1.7 \%$ by weight at the start of the experiment and declined slightly with time. In contrast, barite contained over 60 times less organic carbon at the start of the experiment and organic carbon content varied little over time. Silica contained even less organic carbon $(0.003 \%$, 570 times less than the natural mud) at Day 0; organic carbon increased to levels more comparable to the barite by Days 13 and 15 .

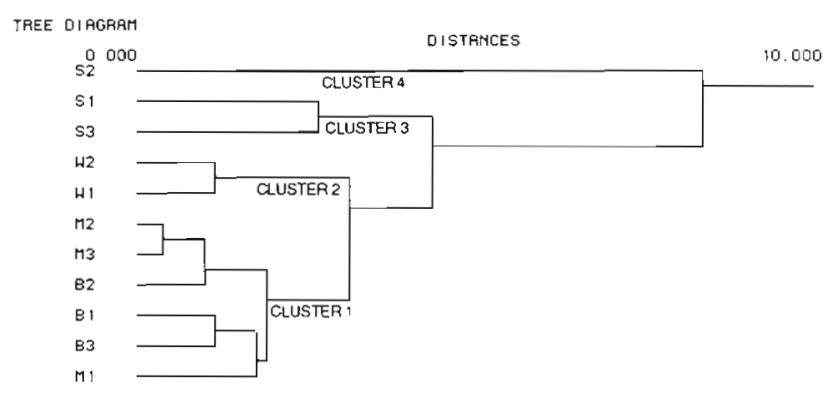

Fig. 2. Dendrogram resulting from cluster analysis of results of community structure analysis of natural mud (M), barite (B) and silica (S) sediments and the overlying water (W) from Day 13 of the barite recolonization experiment. The numbers following the substrata descriptors indicate the subsample number. The Euclidean distance metric and the complete or farthest neighbor linkage methods were used (Ott 1988) 
Table 3. Percent fatty acid composition ${ }^{\circledR}$ for natural mud, barite, silica and overlying water on Day 13 (Expt 2)

\begin{tabular}{|c|c|c|c|c|c|c|}
\hline FAME $^{b}$ & Natural mud & Bante & Silica & Overlying water & $\begin{array}{l}\text { Significance } \\
\text { of ANOVA }\end{array}$ & $\mathrm{SNK}^{\mathrm{c}}$ \\
\hline $14: 0$ & $1.53 \pm 1.20$ & $1.80 \pm 0.29$ & $1.15 \pm 0.46$ & $1.46 \pm 0.75$ & ns & \\
\hline i15:0 & $2.71 \pm 1.52$ & $2.13 \pm 0.59$ & $1.68 \pm 1.14$ & $1.85 \pm 0.00$ & ns & \\
\hline a 15:0 & $4.36 \pm 2.41$ & $3.64 \pm 1.35$ & $1.50 \pm 0.47$ & $0.49 \pm 0.70$ & ns & \\
\hline $15: 0$ & $0.78 \pm 0.28$ & $0.86 \pm 0.16$ & $0.38 \pm 0.21$ & $1.71 \pm 0.09$ & $p<0.01$ & $\underline{O W} \underline{B M} \underline{S}$ \\
\hline $16: 4 w 1$ & $0.33 \pm 0.09$ & $0.00 \pm 0.00$ & $0.00 \pm 0.00$ & $0.00 \pm 0.00$ & $p<0.001$ & $\overline{\mathrm{MB}} \overline{\mathrm{SOW}}$ \\
\hline $16: 2$ & $0.42 \pm 0.14$ & $0.00 \pm 0.00$ & $0.00 \pm 0.00$ & $0.00 \pm 0.00$ & $p<0.001$ & $\overline{\mathrm{MB} \mathrm{S} \mathrm{OW}}$ \\
\hline i 16:0 & $1.13 \pm 0.24$ & $0.91 \pm 0.16$ & $1.38 \pm 0.48$ & $0.00 \pm 0.00$ & $\mathrm{p}<0.001$ & $\overline{\mathrm{SMBOW}}$ \\
\hline $16: 1 w 9$ & $1.77 \pm 0.34$ & $1.04 \pm 0.27$ & $1.24 \pm 0.41$ & $0.87 \pm 0.13$ & ns & \\
\hline $16: 1 w 7$ & $21.41 \pm 2.48$ & $21.87 \pm 1.63$ & $9.77 \pm 5.38$ & $23.57 \pm 1.37$ & ns & \\
\hline $16: 1 w 7 t$ & $0.59 \pm 0.06$ & $0.63 \pm 0.03$ & $0.53 \pm 0.65$ & $0.00 \pm 0.00$ & ns & \\
\hline $16: 1$ w5 & $2.52 \pm 0.31$ & $2.11 \pm 0.57$ & $1.14 \pm 0.70$ & $0.80 \pm 0.03$ & ns & \\
\hline $16: 1 w 13 t$ & $0.18 \pm 0.07$ & $0.32 \pm 0.43$ & $0.71 \pm 0.25$ & $0.33 \pm 0.08$ & ns & \\
\hline $16: 0$ & $17.27 \pm 0.36$ & $21.11 \pm 0.75$ & $15.56 \pm 5.59$ & $21.38 \pm 0.81$ & ns & \\
\hline br17:1 & $0.26 \pm 0.44$ & $0.15 \pm 0.26$ & $0.21 \pm 0.18$ & $0.65 \pm 0.92$ & ns & \\
\hline $10 \mathrm{me} 16: 0$ & $1.52 \pm 0.99$ & $1.00 \pm 0.18$ & $0.56 \pm 0.27$ & $0.00 \pm 0.00$ & $\mathrm{p}<0.02$ & MB S OW \\
\hline i17:0 & $0.96 \pm 0.03$ & $0.76 \pm 0.13$ & $1.62 \pm 0.63$ & $0.00 \pm 0.00$ & $p<0.001$ & $\underline{\mathrm{SMB}} \overline{\mathrm{OW}}$ \\
\hline a17:0 & $2.14+0.16$ & $1.90 \pm 0.63$ & $1.05 \pm 0.31$ & $3.57 \pm 0.11$ & $p<0.01$ & $\overline{\mathrm{OWB}} \overline{\mathrm{MS}}$ \\
\hline cy $17: 0$ & $1.27 \pm 0.22$ & $1.31 \pm 0.58$ & $9.31 \pm 5.41$ & $1.11 \pm 0.91$ & $p<0.01$ & $\overline{S M B O W}$ \\
\hline $17: 0$ & $1.01 \pm 0.10$ & $0.93 \pm 0.11$ & $0.57 \pm 0.31$ & $0.76 \pm 1.07$ & ns & \\
\hline $18: 2 w 6$ & $0.46 \pm 0.12$ & $0.33 \pm 0.29$ & $0.00 \pm 0.00$ & $0.00 \pm 0.00$ & ns & \\
\hline $18: 1 w 9$ & $5.60 \pm 0.86$ & $7.16 \pm 2.22$ & $19.02 \pm 11.81$ & $5.89 \pm 3.02$ & ns & \\
\hline $18: 1 w 7$ & $17.60 \pm 3.30$ & $17.93 \pm 2.00$ & $12.86 \pm 3.97$ & $27.59 \pm 1.24$ & $\mathrm{p}<0.02$ & OW BM $\underline{S}$ \\
\hline $18: 1 w 5$ & $0.54 \pm 0.29$ & $0.00 \pm 0.00$ & $0.00 \pm 0.00$ & $0.00 \pm 0.00$ & $\mathrm{p}<0.01$ & $\underline{\mathrm{M}} \mathrm{BSOW}$ \\
\hline $18: 0$ & $2.65 \pm 0.49$ & $5.18 \pm 1.29$ & $8.19 \pm 2.03$ & $4.77 \pm 0.25$ & $p<0.01$ & $\underline{\mathrm{S}} \overline{\mathrm{MBOW}}$ \\
\hline cy19:0 & $0.65 \pm 0.13$ & $0.77 \pm 0.74$ & $5.71 \pm 4.04$ & $1.82 \pm 0.01$ & ns & \\
\hline $20: 4 w 6$ & $3.72 \pm 1.17$ & $2.13 \pm 0.83$ & $1.93 \pm 1.21$ & $0.74 \pm 0.08$ & ns & \\
\hline $20: 5 w 3$ & $4.20 \pm 1.52$ & $2.48 \pm 1.11$ & $1.70 \pm 1.32$ & $0.63 \pm 0.08$ & ns & \\
\hline $22: 5 w 6$ & $0.61 \pm 0.07$ & $0.51 \pm 0.06$ & $0.74 \pm 0.13$ & $0.00 \pm 0.00$ & $\mathrm{p}<0.001$ & $\underline{\mathrm{S}} \underline{\mathrm{BB}} \underline{\mathrm{OW}}$ \\
\hline $22: 6 w 3$ & $1.45 \pm 0.44$ & $0.94 \pm 0.40$ & $1.50 \pm 0.13$ & $0.00 \pm 0.00$ & $p<0.001$ & $\overline{\mathrm{MB}} \overline{\mathrm{OW}}$ \\
\hline \multicolumn{7}{|c|}{ 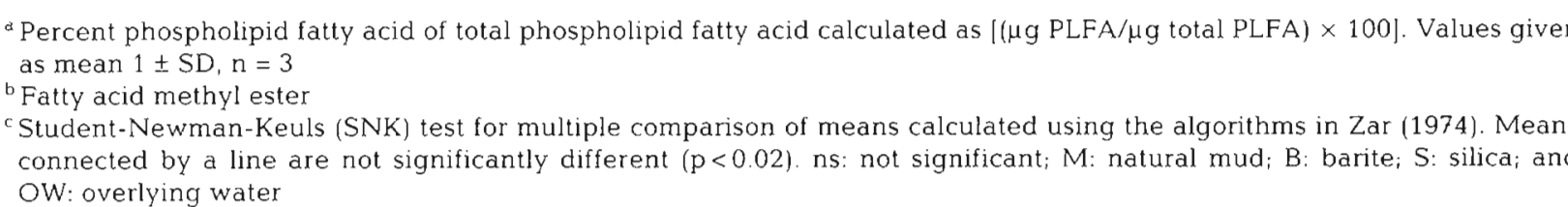 } \\
\hline
\end{tabular}

Direct measurements of the surface area of the 3 sediments indicated a pattern similar to that observed for microbial biomass; barite and silica sediments had similar and low values while the surface area of natural mud was substantially greater (Table 5). Grain-size analysis indicated that barite and silica had similar grain-size distributions, whereas the natural mud had substantially more fine particles (<16 $\mu \mathrm{m}$ ) (Fig. 3).

Table 4. Organic carbon content of fresh bante and silica at time (d) after exposure to seawater in Expt 2. All data given as mean $\pm 1 \mathrm{SD}, \mathrm{n}=3$, except silica, Day 15 where $\mathrm{n}=2$

\begin{tabular}{|lccc|}
\hline \multirow{2}{*}{$\begin{array}{c}\text { Treatment } \\
\text { Day: }\end{array}$} & \multicolumn{3}{c|}{ Organic carbon (weight percent) } \\
& 0 & 13 & 15 \\
\hline Natural mud & $1.717 \pm 0.450$ & $1.620 \pm 0.197$ & $1.567 \pm 0.193$ \\
Barite & $0.027 \pm 0.005$ & $0.033 \pm 0.015$ & $0.027 \pm 0.006$ \\
Silica & $0.003 \pm 0.006$ & $0.023 \pm 0.015$ & $0.010 \pm 0.000$ \\
\hline
\end{tabular}

Theoretical surface areas, calculated assuming spheres with diameters equal to the size at the upper limit of the 10 size classes times the percentage of each class, were similar for barite and silica, but the natural mud grains contained 2 to 3 times as much surface area as

Table 5. Grain size and surface area of natural mud, barite and silica sediments

\begin{tabular}{|lccr|}
\hline Treatment & $\begin{array}{c}\text { Theoretical } \\
\text { surface area } \\
\left(\mathrm{T}, \mathrm{m}^{2} \mathrm{~g}^{-1}\right)\end{array}$ & $\begin{array}{c}\text { Actual } \\
\text { surface area } \\
\left(\mathrm{A}, \mathrm{m}^{2} \mathrm{~g}^{-1}\right)\end{array}$ & $\begin{array}{r}\text { Ratio } \\
\text { (T: A) }\end{array}$ \\
\hline Natural mud & 0.85 & 9.59 & 11.3 \\
Barite & 0.27 & 1.00 & 3.7 \\
Silica & 0.37 & 0.87 & 2.6 \\
'Calculated from grain size-frequency histograms (Fig. 3); \\
see text \\
bata given as a mean of 2 measurements; precision of \\
measurements $0.1 \mathrm{~m}^{2} \mathrm{~g}^{-1}$
\end{tabular}




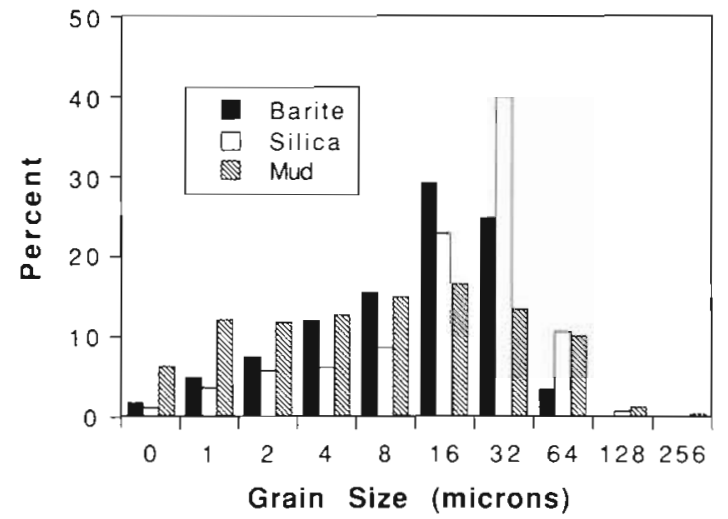

Fig. 3. Sediment grain-size distributions of the barite, silica and natural mud sediments used in the colonization experiments

barite and silica. Differences among sediment types in theoretical surface areas were less than empirically derived measures of surface area, probably due to deviations from sphericity and grain surface roughness (see 'Discussion'). Measured surface areas exceeded predicted surface areas by a factors of 3.7 and 2.6 for barite and silica sediments, respectively. For natural mud, measured surface areas exceeded predicted surface areas by a factor of 11.3 .

\section{DISCUSSION}

\section{Microbial colonization rates}

Initial colonization of freshly deposited sediments in marine systems is not well studied, but insight concerning colonization rates can be gleaned from the waste-water treatment literature and from longer-term studies in aquatic systems. Under conditions of high carbon loading, such as those found in aerobic fixedbed reactors, microbial colonization of the bed (expanded schist grains) is known to occur quite rapidly, with detectable biomass present within $24 \mathrm{~h}$ and stable microbial biomass being reached within $5 \mathrm{~d}$ (Giuliano \& Joret 1988). In a similar study using anaerobic fluidized-bed reactors, Lauwers et al. (1990) found that microbial colonization of the bed (sand) was also rapid (detectable biomass within $24 \mathrm{~h}$ ), and biomass continued to increase throughout the study period ( 8 to $12 \mathrm{~d}$ ). We are unaware of studies that have quantified initial microbial colonization rates and community structure for marine sediments with very low carbon content (e.g. analogous to initial deposition of abiotic material); rather, the studies have focussed on maturation times. Hirsch \& Rades-Rohkohl (1990), for example, found that after $12 \mathrm{wk}$ of in situ incubation, sediment stripped of organic carbon contained similar bacterial abundances as ambient ground-water sediments. In contrast, Yamamoto \& Lopez (1985) found bacterial abundance stabilized after only $6 \mathrm{wk}$ in microcosms containing artificial sediments composed of either glass beads, silica or kaolin clay incubated in sea water Likewise, within this 6 to 12 wk range is the study of Smith et al. (1982) who found that after $8 \mathrm{wk}$ exposure to unfiltered, flowing sea water, sediments overlaid with 1 to $2 \mathrm{~mm}$ of fresh barite and control sediments contained similar microbial biomass. These studies suggest that initial microbial colonization of fresh sediments should proceed over the course of several days to weeks.

Initial microbial colonization of the freshly deposited barite and silica sediments was relatively slow in the present study. After 48 h, both treatments contained ca 60 times less microbial biomass than the natural mud, and little change was observed until Day 13 of the experiment, when microbial biomass began to increase (Table 1). Even after $15 \mathrm{~d}$, microbial biomass in the natural mud was still 15 to 20 times higher than in barite or silica. These colonization rates are slow compared to those determined for systems with high organic carbon loading (e.g Giuliano \& Joret 1988 , Lauweres et al. 1990). Our results cannot be meaningfully compared to the studies conducted in other systems with low organic carbon (e.g Smith et al. 1982, Yamamoto \& Lopez 1985, Hirsch \& Rades-Rohkohl 1990) because the minimum duration of these experiments before sampling was $6 \mathrm{wk}$, and none of these studies attempted to simulate a realistic field flow regime.

Local enhancement of microbial populations in regions of relatively high boundary shear velocity (and thus, regions of relatively high nutrient flux to the bed), as measured in a laboratory flume (Eckman 1985) and inferred from field sampling (Thistle et al. 1984), suggest that microbial colonization rates may be positively correlated with boundary shear velocity. The hydraulically smooth, turbulent flow tested here, with a $u$. of $0.30 \mathrm{~cm} \mathrm{~s}^{-1}$, was at about the midpoint of the range of $u$. determined for tidally driven flows in shallow coastal embayments (e.g. Butman 1986). This $u$. was not sufficient, however, to initiate motion of the natural mud, barite and silica used in this study (pers. obs.). In continental shelf regions of exploratory and production drilling, such as Georges Bank, Massachusetts and the Mid-Atlantic Bight (Butman 1987. Lyne et al. 1990) and the Santa Maria Basin in southern California (Drake et al. 1992), values of $u_{{ }}$, the boundary shear velocity due to currents (responsible for upward mixing of suspended sediment) were typically between about 0.3 and $3 \mathrm{~cm} \mathrm{~s}^{-1}$. Values of

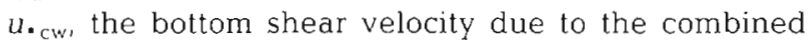
effects of waves and currents (responsible for initiating 
sediment motion), were as high as $7 \mathrm{~cm} \mathrm{~s}^{-1}$ for storms (non-storm periods are typically defined as periods where $u \cdot \mathrm{cw}<1.4 \mathrm{~cm} \mathrm{~s}^{-1}$ ). Microbial colonization rates of barite observed in this laboratory flume study may thus be a conservative estimate of colonization rates of barite initially deposited at continental shelf depths.

In the present study, the organic carbon content of the sediment treatments provides a proximal cause for the observed distributions of microbial biomass. The barite and silica sediments contained 60 to 570 times less organic carbon at the start of Expt 2 than did the natural mud (Table 4) and the increase in microbial biomass roughly corresponded to an increase in organic carbon on Day 13. The fine structure of marine sediments is still a subject of debate (for example, see DeFlaun \& Mayer 1983, Watling 1988), but most natural marine sediments are thought to be a composite of inert mineral grains coated and bridged by organic malter. Of this organic matter, a small firaction $(>10 \%)$ is commonly thought to be living biomass. The rest is considered to be detrital in nature and subject to microbial decomposition. Using a ratio of $191.7 \mu \mathrm{g}$ bacterial carbon per $100 \mathrm{nmol}$ of phospholipid phosphate (Findlay et al. 1989), living microbial biomass accounts for approximately $1 \%$ of organic carbon in the natural mud. If this ratio of living to detrital carbon is applied to barite and silica sediments, the expected range of microbial biomass is 0.22 to $3.3 \mathrm{nmol}$ of phospholipid phosphate. This compares favorably to the measured 0.58 to $4.49 \mathrm{nmol}$ of phospholipid phosphate and suggests that carbon limitation is the proximate cause of the low microbial biomass in the fresh sediments.

DeFlaun \& Mayer (1983) have argued that the surface area of sediments directly influences both the organic carbon content and the bacterial biomass of sediments. A comparison of sediment surface areas measured directly, using the nitrogen sorption technique, and theoretically calculated for spherical particles provides a rough estimate of deviations from sphericity and the surface roughness of the particles. Measured surface areas exceeded the theoretical calculations by factors of 3 to 4 for barite and silica and by over a factor 10 for natural mud (Table 5). The average grain size and the distribution of grain sizes (Fig. 3) were similar for barite and silica, but natural mud contained a higher percentage of fine particles. Differences between the sediments in measured surface area can be attributed primarily to differences in the surfaces of the grains. Mineral grains in the marine environment are known to undergo chemical weathering, a process that produces pits and other areas of low relief that greatly increase the surface area of the grains. The difference between natural mud and the 2 'fresh' substrates, barite and silica, in availability of grain-surface relief for carbon scavenging and micro bial attachment area is, in our opinion, the most likely cause of the low microbial biomass in barite and silica.

Several workers (i.e. Weiler \& Mills 1965, Tanoue \& Handa 1979, Mayer et al. 1985) have hypothesized that the vast majority of organic matter in sediments exists as a monolayer on the surface of the sediment grains. In cases of high carbon flow to the benthos additional carbon may exist within the sediment matrix, but for the most part our experimental design restricted carbon flow. Theoretical and experimental data indicate that monolayer coverage should yield approximately 0.5 to $1.5 \mathrm{mg} \mathrm{C} \mathrm{m}^{-2}$ (Arnold \& Pak 1962, Suess 1973, Mayer et al. 1985). The surface-area-specific carbon levels for natural mud, barite and silica (calculated using the pooled carbon measurements from Days 13 and 15) were 1.66, 0.30, and $0.20 \mathrm{mg} \mathrm{C} \mathrm{m}^{-2}$. respectively. Hence, the 'fresh' nature of both the barite and silica probably contributed, in several ways, to the low microbial biomass associated with these substrates. The low carbon content of these sediments limits microbial biomass. The low carbon content of these sediments is due, in part, to the lack of a monolayer of organic matter and, in part, to their low surface area. We predict that, given sufficient time, surfacearea specific carbon values for barite and silica would increase to levels predicted from monolayer coverage of the grains and that actual surface areas would increase, approaching those of the natural mud. This would eventually result in similar microbial biomass in all three sediment types.

Surface morphology of sediment grains can affect not only total microbial biomass, but the community structure of the microbiota as well (Nickels et al. 1981). Bacteria and microalgae concentrate in areas of low relief, i.e. surface fissures, crevices, cleavage ledges and concave abrasions (Meadows \& Anderson 1967, Weise \& Rheinheimer 1978, Nickels et al. 1981, Hoppe 1984, Mayer et al. 1985), and total microbial biomass tends to be higher on grains with more surface irregularities. Smooth grains, while supporting fewer procaryotes and microalgae, tend to support larger populations of microeucaryotic grazers (Nickels et al. 1981)

\section{Microbial community structure}

Just as the amount of phospholipid phosphate can be related to the total microbial biomass present in a sample, the amount the individual phospholipid fatty acids can be related to the biomass of specific groups of microorganisms that contain the individual fatty acids (for a current review see Vestal \& White 1989; for a detailed discussion of the interpretation of PLFA profiles see Findlay \& Dobbs in press). The relation- 
ships between groups of microorganisms and specific fatty acids have been explored using pure culture studies, mixed enrichment cultures and manipulative laboratory and field experiments. Basically, communities can be divided into eucaryotic and procaryotic components. The eucaryotic component can be further subdivided into 2 functional groups (heterotrophs and phototrophs) whereas the procaryotic component can be divided into an aerobic and 2 anaerobic functional groups (Findlay et al. 1990a). Due to the large disparity in biomass between treatments, comparisons of the biomass of specific functional groups revealed little additional information than would be predicted from the total biomass measures (for example, the biomass of sulfate-reducing bacteria in natural mud was greater than in barite and silica which, in turn, was greater than in the overlying water). Expressing each fatty acid as a percentage of the total phospholipid fatty acids, however, allows comparisons of the microbial community structure that are independent of microbial biomass. This technique, unfortunately, has the disadvantage of being disproportionately sensitive to changes in the amounts of rare fatty acids. Changes in rare fatty acids result in greater relative changes than similar changes in common fatty acids. Transformation $[\ln (x+1)]$ after ratio formation reduces this tendency and also helps to maintain normality of the data. The advantage of this technique is that it permits comparison of the relative importance of functional groups within the microbial community.

Analysis of the microbial community after $13 \mathrm{~d}$ of incubation indicated that, despite the large difference in total biomass, microbial communities in the natural mud and barite treatments were similar in structure, whereas the silica community was highly variable and dissimilar to the natural mud community. The flowing sea water community was more similar to the microbial communities in natural mud and barite than in silica (Fig. 2). The PLFAs that differed between the sediment treatments and between the sediments and the overlying water (Table 3) provide insight into the functional groups of microbes colonizing barite and silica, relative to those comprising the source populations (i.e. natural mud and sea water).

Natural mud contained several trace $(<1 \%)$ fatty acids $(16: 4 \mathrm{w} 1,16: 2,18: 1 \mathrm{w} 5)$ not found in any of the other treatments. These fatty acids are common in photosynthetic organisms and 16:4w1 is considered a biomarker for diatoms. These organisms must have been present in the mud at the time of collection and persisted (but did not reproduce). Their absence in the overlying water is curious; perhaps they were removed during the initial filtering of the water during the set-up phase of the experiment. The overlying water also contained significantly less of the fatty acids 22:5w6, 22:6w3, i17:0, 10Me16:0 and i16:0. Two of these (the 22-carbon fatty acids) are common in marine photosynthetic and heterotrophic eucaryotic organisms. The others are common in sulfate-reducing bacteria. The overlying water contained significantly more of 2 common fatty acids $\{15: 0$ and a 17:0) that are distributed widely among bacteria and photosynthetic microeucaryotes. The significance of this increase is unknown. Given the above, the microbial community of the overlying water can be differentiated from those communities present in the sediments by its lack of sulfate-reducing bacteria and the absence of a portion of the microeucaryotic community.

The PLFAs recovered from the silica sediments were significantly different from those recovered from all other treatments in several aspects. Silica was higher in fatty acids i17:0, cy 17:0, 18:0 and 22:5w6, lower in fatty acids $15: 0$ and $a 17: 0$, and showed a reversal in the usual ratio of $18: 1 \mathrm{w} 7 / 18: 1 \mathrm{w} 9$. While many microorganisms contain both cis-18:1w7 and 18:1w9, many bacteria form these fatty acids via a different pathway than other organisms. The result is that in bacteria (and hence most bacterially dominated microbial communities) 18:1w7 predominates, whereas in microeucaryotic organisms 18:1w9 predominates. Many (if not most) microbial communities from marine sediments are dominated by procaryotes and, as expected, $18: 1 w 7$ is the more abundant fatty acid. The shift in the ratio of $18: 1$ w7/18:1w9 suggests an increase in the importance of microeucaryotes within the microbial community associated with the silica sediments. The significant increase in 22:5w6 supports this conclusion and suggests that heterotrophic microeucaryotes have increased. Bacteria, with the exception of some barophilic species, do not contain polyenoic fatty acids and, as with 18:1w7/18:1w9, polyenoic fatty acids of different unsaturation patterns predominate in different functional groups of microeucaryotic organisms. Among photosynthetic microorganisms fatty acids of the 'omega 3' family predominate (usually 10:1, w3/w6) and among heterotrophic microorganisms those of the 'omega 6' family predominate (usually $1: 1$ to $1: 3$, w3/w6). Hence, the PLFA analysis indicates heterotrophic microeucaryotic organisms comprise a significantly greater proportion of the microbial community in the silica treatment than in the other sediment types.

The other fatty acids that were relatively more abundant in silica than in the other sediments are generally associated with bacteria and, in particular, with sulfate-reducing and other anaerobic bacteria. Initially, it seems contradictory that there could be an increase in the relative abundance of sulfate-reducing bacteria and other anaerobes in sediments that also show an increase in heterotrophic microeucaryotes. However, several studies have shown that disturbance 
(including predation) differentially removes aerobic bacteria and results in a community with elevated abundances of sulfate-reducing bacteria and other anaerobes (Findlay et al. 1990a, b, Mayer et al. 1992). The increase in heterotrophic microeucaryotes has most likely led to an increase in predation resulting in a loss of aerobic bacteria. The relative smoothness of the grains, observed in SEM photographs (Findlay unpubl. data) and reflected in the low measured surface areas, likely increased the susceptibility of bacteria to predation. Nickels et al. (1981) found a similar pattern of higher heterotrophic eucaryotic biomass and lower procaryotic biomass when comparing natural, weathered sands to glass beads.

The silica sediments also contained significantly lower amounts of fatty acids 15:0 and a17:0. As stated above, these are common fatty acids distributed widely among bacteria and photosynthetic microeucaryotes. The significance of this decrease is unknown. It is interesting that these fatty acids (15:0 and a17:0) increased in the overlying water. This suggest that a similar functional group of microorganisms (currently unidentified) relatively increased in the overlying water and decreased in the silica sediments.

The PLFAs recovered from the barite sediments were never significantly different from all other treatments and, with the exception of the three trace fatty acids previously discussed, never differed significantly from the PLFAs recovered from the natural mud. This high degree of similarity is reflected in the inclusion of all the barite and natural mud replicates in a single group by cluster analysis (Fig. 2). These results indicate that there was little difference between the microbial community (other than in total biomass) that developed in the barite sediments and the community present in the natural mud. These results support the findings of Smith et al. (1982) where there were no consistent differences in microbial populations between control sands and sands overlaid with 1 and $2 \mathrm{~mm}$ of barite. The Smith et al. (1982) study was conducted in the Gulf of Mexico, used flowing sea water and was approximately $8 \mathrm{wk}$ in duration. Together, our results and those of Smith et al. (1982) indicate that barite, if exposed to sea water for a sufficient period of time, will develop a microbial community comparable to the community present in natural marine sediments. However, this conclusion should not be interpreted to indicate that drilling muds will have little or no effect on the marine environment as Smith et al. (1982) found that other components of drilling mud (Aldacide ${ }^{\infty}$, Surflo ${ }^{\oplus}$, Dowicide ${ }^{\otimes}$ ) caused significant alteration in the microbial community. Furthermore, because the flume flow in this study was slow compared to typical flows even during non-storm conditions on continental shelves, microbial colonization rates indicated here are likely to be conservative (i.e. faster colonization rates are likely to occur in flows with substantially higher $u$. because of enhanced nutrient flux to the bed, e.g. Eckman 1985).

\section{Implications for benthic ecology}

These results suggest that barite discharged into the marine environment and settling onto surface sediments will remain relatively carbon-free and axenic for up to a maximum period of about $2 \mathrm{wk}$, but will eventually develop a microbial community similar in biomass and structure to that of the underlying sediments. The similar, qualitative responses of the microbial community to barite and silica argue against any 'inhibitory' effects of barite on microbial colonization and suggest that properties common to both substrates are responsible for their relatively low microbial biomass and slow colonization rates. These responses define a period of time from days to weeks during which barite particles would be exotic, and therefore, could potentially affect natural ecological processes.

Freshly deposited, axenic barite may affect infaunal communities by altering the food available to surface deposit feeders; with no initial microbial population, barite may be a poor food source for resident macrofauna (Hobbie \& Lee 1980, Smith et al. 1982). Furthermore, larvae of macrofauna that feed on microbes may not colonize sediments covered with barite until sufficient microbial populations are established on the particles (Tenore \& Rice 1980, Yingst \& Rhoads 1980). Likewise, larvae that use sediment grain size as a cue for settlement (e.g. Wilson 1952, 1953a, b) may avoid an otherwise acceptable habitat covered with a thin layer of barite. If, however, barite eventually accumulates organics and develops microbial communities similar in abundance and composition to those on natural sediments, then areas with substantial barite input could represent an enriched food source for deposit feeders because barite would shift the ambient sediment grain-size distribution toward the smaller grain sizes (see 'Introduction'), and smaller particles tend to have more bacteria per unit volume.

Results of this study suggest, for example, that larval settlement of benthic invertebrates could differ between sediment covered with newly deposited barite and natural sediments, depending on the sedimentspecificity of the invertebrate larvae. In fact, in laboratory flume experiments, a $3 \mathrm{~mm}$ thick layer of fresh (i.e. axenic) barite on top of a preferred, natural, muddy sediment depressed settlement of larvae of the deposit-feeding polychaete Capitella sp. I (Butman \& Grassle 1992), whereas still-water choice experiments with larvae of the suspension-feeding bivalve 
Mercenaria mercenaria showed no apparent effect of a barite layer on sediment selection (Bachelet et al. 1992). Capitella sp. I larvae are known to be highly selective among natural substrates (Grassle et al. 1992), whereas larvae of $M$. mercenaria generally are not (e.g. Bachelet et al. 1992).

A thin barite layer is unlikely to remain on top of the sediment surface under natural flow conditions in regions of interest for oil exploration because physical transport and biological processes will resuspend and mix barite with ambient sediments (e.g. Butman 1987, Twichell et al. 1987, Drake et al. 1992). Resuspension and mixing with natural sediments may, in fact, speed up the colonization process by weathering the barite particles and increasing exposure to carbon and microbe sources.

The extent to which fresh barite, at realistic concentrations for exploratory or production drilling areas, can actually dilute natural sediments as food for macrofauna is unclear, especially considering the controversy regarding what actually constitutes 'food' for deposit feeders (e.g. Lopez \& Levinton 1987, Lopez et al. 1989). A study that directly addressed barite effects on aspects of the ecology of the subsurface, depositfeeding polychaete Mediomastus ambiseta showed no significant effects on adult feeding, growth, survival and reproductive status for treatments where a $1 \mathrm{~mm}$ layer of barite was placed on top of a natural, muddy sediment and where barite was mixed with the mud at concentrations of 0.1 to $10 \%$, by volume (Starczak et al. 1992). Adults did migrate, however, out of $100 \%$ barite into natural mud. Concentrations of barite in the barite-sediment mixtures tested in Starczak et al. (1992) were well within the range of those measured at production (e.g. Gettleson \& Laird 1980) and exploratory (e.g. Bothner et al. 1986, Hyland et al. 1991) drilling areas, and within the range of pre-drilling, background concentrations measured at oil and gas lease sites (Hyland et al. 1990). Effects on juveniles were not explored by Starczak et al. (1992), however, and they could be more profound because juveniles have faster growth rates and are generally more susceptibility to disturbances.

This study is the first to have documented microbial colonization of abiotic particles in a controlled and realistic flow regime. However, because the boundary shear velocity of the flume flow was at the low end of the range of shear velocities measured on continental shelves, because no sediment transport occurred in this flow, and because of the absence of other organisms in the sediment, colonization rates determined here may represent a conservative end-member of the range of rates that could occur under natural conditions in the field. The sensitivity of microbial growth and reproduction to nutrient supply (e.g. Jumars \&
Nowell 1984) suggests that colonization rates are likely to be flow-regime dependent; colonization is expected to be positively related to boundary shear velocity (e.g. Eckman 1985). Sediment transport could affect microbial colonization rates on abiotic particles either positively, for example, by weathering smooth particles and thus enhancing the particle surface area for organic-carbon scavenging and microbial attachment (see previous discussion), or negatively, for example, by physically abrading microbes from the particles, particularly in sandy habitats (e.g. Miller 1989). Furthermore, because scaling arguments suggest that an important parameter determining food availability to deposit-feeding invertebrates is the ratio of particle residence time within the feeding pool to microbial doubling time (Miller et al. 1984), meaningful experiments on microbial colonization of abiotic particles as a food source for benthic invertebrates should include both particle transport and bioturbation.

Acknowledgements. This research was supported by a Minerals Management Service (U.S. Dept. of the Interior) contract (14-12-0001-30262) to C.A.B. We would like to thank P. V. R. Snelgrove for assistance with the flume, C. H. Clifford for CHN analysis, F. W. Valoif for direct counts, K. R. Hardy and $T E$. Sawyer for assistance with analysis of total microbial biomass and community structure, A. M. Moffett for grainsize analyses, L. Shick for surface-area measurements and $K$. Banks for help with other aspects of the experiments. $V$. R. Starczak and 2 anonymous reviewers provided valuable advice on experimental design and the statistics, but we take ultimate responsibility for our experimental design and choice of statistical analyses. We also thank the U.S. Silica Company in Berkeley Springs (WV, USA) for supplying the silica and the American Petroleum Institute in Dallas (TX, USA) for supplying the barite. V. R. Starczak and D. F. Boesch provided valuable comments on an earlier version of this manuscript. This is contribution number 253 from the Darling Marine Center and contribution number 7856 from the Woods Hole Oceanographic Institution.

\section{LITERATURE CITED}

Aller, R. C., Yingst, J. Y. (1985). Effects of the marine depositfeeders Heteromastus filiformis (Polychaeta), Macoma balthica (Bivalvia), and Tellina texana (Bivalvia) on averaged sedimentary solute transport, reaction rates, and microbial distributions. J. mar. Res. 43: 615-645

Arnold, J. D., Pak, C. Y. C. (1962). Protein-protein interaction at the air-water interface. J. Colloid Sci. 17: $348-362$

Bachelet, G., Butman, C. A., Webb, C. M., Starczak, V. R., Snelgrove, P. V. N. (1992). Non-selective settlement of Mercenaria mercenaria (Linné) larvae in short-term, stillwater, laboratory experiments. J. exp. mar. Biol. Ecol. 161: 241-290

Baier, R. E. (1984). Initial events in microbial film formation. In: Costlow, J. D., Tipper, R. C. (eds.) Marine biodeterioration: an interdisciplinary study. Naval Institute Press, Annapolis, p. 57-62 
Boesch, D. F., Rabalais, N. N. (eds.) (1987). Long-term environmental effects of offshore oil and gas development. Elsevier Applied Science, New York

Bothner, M. H., Rendigs, R. R., Campbell, E., Doughten, M. W., Parmenter, C. M., O'Dell, C. H., DiLsio, G. P. Johnson, R. G., Gillison, J. R., Rait, N. (1986). The Georges Bank Monitoring Program 1985: analysis of trace metals in bottom sediments during the third year of monitoring. U.S. Geol. Survey Circular, Vol. 988, U.S.G.S., Woods Hole, MA

Brinch-Iversen, J., King, G. M. (1990). Effects of substrate concentration, growth state, and oxygen availability on relationships among bacterial carbon, nitrogen and phospholipid phosphorus content. FEMS Microbiol. Ecol. 74: 345-356

Brunauer, S., Emmett, P., Teller, E. (1938). Adsorption of gasses in multimolecular layers. J. Am. Chem. Soc. 60 309-319

Butman, B. (1987). Physical processes causing surficialsediment movement. In: Backus, R. H. (ed.) Georges Bank. MIT Press, Cambridge, p. 147-162

Butman, C. A. (1986). Larval settlement of soft-sediment invertebrates: sone predictions based on an analysis of nearbottom velocity profiles. In: Nihoul, J. C. J. (ed.) Marine interfaces ecohydrodynamics. Elsevier, Amsterdam, p. $487-514$

Butman, C. A., Chapman, R. J. (1989). The 17-Meter Flume at the Coastal Research Laboratory. Part I. Description and users manual. WHOI Tech. Rept. 89-10

Butman, C. A., Grassle, J. P. (1992). Active habitat selection by Capitella sp. I larvae. I. Two-choice experiments in still water and flume flows. J. mar. Res. 50:669-715

Cammen, L. M. (1982). Effect of particle size on organic content and microbial abundance within four marine sediments. Mar. Ecol. Prog. Ser. 9: 273-280

Cantelmo, F. R., Tagatz, M. E., Ranga Rao, K. (1979). Effect of barite on meiofauna in a flow-through experimental system. Mar. environ. Res. 2: 301-309

Carls, M. G., Rice, S. D. (1984). Toxic contributions of specific drilling mud components to larval shrimp and crabs. Mar. environ. Res. 12: 45-62

Characklis, W. G., Marshall, K. C. (1990). Biofilms. John Wiley and Sons, New York

Dale, N. G. (1974). Bacteria in intertidal sediments: factors related to their distribution. Limnol. Oceanogr. 19: 509-518

DeFlaun, M. F., Mayer, L. M. (1983). Relationships between bacteria and grain surfaces in intertidal sediments. Limnol. Oceanogr. 28: 873-881

Dobbs, F. C., Guckert, J. B. (1988). Callianassa trilobata (Crustacea: Thalassinidea) influences abundance of meiotauna and biomass, composition, and physiologic state of microbial communities within its burrow. Mar. Ecol. Prog. Ser. 45: 69-79

Drake, D. E., Cacchione, D. A., Butman, B., Butman, C. A. (1992). Special study on sediment transport and bioturbation: Bottom boundary layer flow and sediment transport on the outer shelf and upper slope off central California. U.S. Geol. Surv. Open File Report 92-188, U.S.G.S., Menlo Park, CA

Eckman, J. E. (1985). Flow disruption by an animal-tube mimic affects sediment bacterial colonization. J. mar. Res. 43: 419-435

Escher, A. R., Characklis, W. G. (1988). Microbial colonization of a smooth substratum: a kinetic analysis using image analysis. Wat. Sci. Tech. 20: 277-283

Escher, A. R., Characklis, W. G. (1990). Modeling the initial events in biofilm accumulation. In: Characklis, W. G.,
Marshall, K. C. (eds.) Biofilms. John Wiley \& Sons, New York, p. $445-486$

Federle, T W., Livingston, R. J., Metter, D. A., White, D. C. (1983). Modification of estuarine sedimentary microbiota by exclusion of epibenthic predators. J. exp. mar. Biol. Ecol. 73: 81-94

Findlay, R. H., Dobbs, F. C. (in press) Quantitative description of microbial communities using lipid analysis. In: Kemp, P. F., Sherr, B. F., Sherr, E. B., Cole, J. J (eds.) Current methods in aquatic microbial ecology. Lewis Publishing, Chelsea

Findlay, R. H., King, G. M., Watling, L. (1989). Efficacy of phospholipid analysis in determining microbial biomass in sediments. Appl environ. Microbiol. 54: 2888-2893

Findlay, R. H., Trexler, M. B., Guckert, J. B., White, D. C. (1990a). Laboratory study of disturbance in marine sediments: response of a microbial community. Mar. Ecol. Prog. Ser. 62: 121-131

Findlay, R. H., Trexler, M. B., White, D. C. (1990b). Response of a benthic microbial community to biotic disturbance. Mar. Ecol. Prog. Ser. 62: 135-148

Gettleson, D. A., Laird, C. E. $\{1980\}$. Benthic barium levels in the vicinity of six drill sites in the Gulf of Mexirn. In: Symposium/research on environmental fate and effects of drilling fluids and cuttings. American Petroleum Institute, Washington, DC, p. 382-418

Gibbs, R. J (1977). Effect of combustion temperature and time, and of oxidation agent used in organic carbon and nitrogen analyses of sediments and dissolved organic material. J. sedim. Petrol. 47: 547-550

Giuliano, C., Joret, J. C. (1988). Distribution, characterization. and activity of microbial biomass of an aerobic fixed-bed reactor. Wat. Sci. Tech. 20:455-457

Gooday, A. J., Turley, C. M. (1990). Responses of benthic organisms to inputs of organic matter to the ocean floor: a review. Phil. Trans. R. Soc. Lond. Ser. A 331: 119-138

Grassle, J. F., Grassle, J. P., Brown-Leger, L. S., Petrecca R. F., Copley, N. J. (1985). Subtidal macrobenthos of Narragansett Bay. Field and mesocosm studies of the effects of eutrophication and organic input on benthic populations. In: Gray, J. S., Christiansen, M. E. (eds.) Marine biology of polar regions and effects of stress on marine organisms. John Wiley \& Sons, New York, p. $421-434$

Grassle, J. P., Butman, C. A., Mills, S. W. (1992). Active habitat selection by Capitella sp. I larvae. II. Multiple-choice experiments in still water and flume flows. J. mar. Res. 50: $717-743$

Gross, T F., Nowell, A. R. M. (1983). Mean flow and turbulence scaling in a tidal boundary layer. Cont. Shelf Res. 2 $109-126$

Hargrave, B. T (1972). Aerobic decomposition of sediment and detritus as a function of particle surface area and organic content. Limnol. Oceanogr. 17: 583-596

Hirsch, P., Rades-Rohkohl, E. (1990). Microbial colonization of aquifer sediment exposed in a groundwater well in northern Germany. Appl. environ. Microbiol. 56 2963-2966

Hobbie, J. E., Lee, C. (1980). Microbial production of extracellular material: importance in benthic ecology. In: Tenore, K. R., Coull, B. C. (eds.) Marine benthic dynamics. Univ of South Carolina Press, Columbia, p. $341-346$

Hoppe, H. G. (1984). Altachment of bacteria: advantage or disadvantage for survival in the aquatic environment. In Marshall, K. C. (ed.) Microbial adhesion and aggregation Springer-Verlag, New York, p. 283-301 
Hyland, J., Hardin, D., Crecelius, E., Drake, D., Montagna, P., Steinhauer, M. (1990). Monitoring long-term effects of offshore oil and gas development along the southern California outer continental shelf and slope: background environmental conditions in the Santa Maria Basin. Oil chem. Pollut. 6: 195-240

Hyland, J., Hardin, D., Steinhauer, M., Coats, D., Green, R., Neff, J. (1991). Environmental impact of offshore oil and gas development on the outer continental shelf and slope off Point Arguello, California. In: California OCS Phase II Monitoring Program Final Report (OCS Study, MMS 910083), prepared by Battelle Ocean Sciences, Duxbury, MA, p. 9-1-9-46

Jumars, P. A., Nowell, A. R. M. (1984). Fluid and sediment dynamic effects on marine benthic community structure. Am. Zool. 24: 45-55

Keevil, C. W. (1989). Chemostat model of human and aquatic corrosive biofilms. In: Hattori, T., Ishida, Y., Maruyama, Y., Morita, R. Y., Uchida, A. (eds.) Recent advances in microbial ecology. Japan Scientific Societies Press, Tokyo, p. $151-156$

Kogure, K. (1989). Attachment of aquatic bacteria overview. In: Hattori, T., Ishida, Y., Maruyama, Y., Morita, R. Y., Uchida, A. (eds.) Recent advances in microbial ecology. Japan Scientific Societies Press, Tokyo, p. $131-134$

Lauwers, A. M., Heinen, W., Gorris, L. M. G., van der Drift, C. (1990). Early stages in biofilm development in methanogenic fluidized-bed reactors. Appl. microbiol. Biotechnol. 33: $352-358$

Lopez, G. R., Levinton, J. S. (1987). Ecology of deposit-feeding animals in marine sediments. Quart. Rev. Biol. 62: $235-259$

Lopez, G., Taghon, G., Levinton, J. (eds.) (1989). Ecology of marine deposit feeders. Springer-Verlag, New York

Lyne, V. D., Butman, B., Grant, W. D. (1990). Sediment movement along the U.S. east coast continental shelf. II. Modelling suspended sediment concentration and transport rate during storms. Cont. Shelf Res. 10:429-460

Macdonald, J. M., Sheilds, J. D., Zimmer-Faust, R. K. (1988). Acute toxicities of eleven metals to early life-history stages of the yellow crab Cancer anthonyi. Mar. Biol. 98: 201-207

Mayer, L. M., Macko, S. A., Cammen, L. (1988). Provenance, concentration and nature of sedimentary organic nitrogen in the Gulf of Maine. Mar. Chem. 25: 291-304

Mayer, L. M., Rahaim, P., Guerin, W., Macko, S. A., Watling, L. Anderson, F. E. (1985). Biological and granulometric controls on organic matter on an intertidal mudflat. Estuar coast. Shelf Sci. 20: 491-503

Mayer, L. M., Schick, D. F., Findlay, R. H., Rice, D. L. (1992). Effects of commercial dragging on sedimentary organic matter. Mar environ. Res. 31. 249-261

Meadows, P. S., Anderson, J. G. (1967). Microorganisms attached to marine sand grains. J. mar. biol. Ass. U.K. 48: $161-175$

Menzie, C. A. (1982). The environmental implications of offshore oil and gas activities. Environ. Sci. Technol. 16: 454A-472A

Miller, D. C. (1989). Abrasion effects on microbes in sandy sediments. Mar. Ecol. Prog. Ser. 55: 73-82

Miller, D. C., Jumars, P. A., Nowell, A. R. M. (1984). Effects of sediment transport on deposit feeding: scaling arguments. Limnol. Oceanogr. 29: 1202-1217

Miller, M. C., McCave, N., Komar, P. D. (1977). Threshold of sediment motion under unidirectional currents. Sedimentology 24: $507-527$
Myers, J L. (1979). Fundamentals of experimental design. Allyn and Bacon, Inc., Boston

National Research Council. (1983). Drilling discharges in the marine environment. National Academy Press, Washington, DC

Neff, J. M. (1987). Biological effects of drilling fluids, drill cuttings and produced waters. In: Boesch, D. F., Rabalais, N. N. (eds.) Long-term environmental effects of of fshore oil and gas development. Elsevier Applied Science, New York, p. 469-536

Nickels, J. S., Bobbie, R. J., Martz, R. F., Smith, G. A., White, D. C., Richards, N. L. (1981). Effect of silicate grain shape, structure and location on the biomass and community structure of colonizing marine microbiota. Appl. environ. Microbiol. 41: 1261-1268

Nowell, A. R. M., Jumars, P. A. (1984). Flow environments of aquatic benthos. A. Rev. Ecol. Syst. 15: 303-328

Ott, L. (1988). An introduction to statistical methods and data analysis. PWS-KENT Publishing Company, Boston

Reichardt, W. (1988). Impact of bioturbation by Arenicola marina on microbiological parameter in intertidal sediments. Mar. Ecol. Prog. Ser. 44:149-158

Rublee, P. A., Dornseif, B. E. (1978). Direct counts of bacteria in the sediments of a North Carolina salt marsh. Estuaries 1: $188-191$

Sanders, H. L. (1958). Benthic studies in Buzzards Bay. 1 Animal-sediment relationships. Limnol. Oceanogr. 3: $245-258$

Smith, G. A., Nickels, J. S., Bobbie, R. J., Richards, N. L., White, D. C. (1982). Effects of oil and gas well-drilling fluids on the biomass and community structure of microbiota that colonize sands in running seawater. Arch. environ. Contam. Toxicol. 11: 17-23

Snelgrove, P. V. R., Grassle, J. F., Petrecca, R. F. (in press). The role of food patches in maintaining high deep sea diversity: field experiments using hydrodynamically unbiased colonization trays. Limnol. Oceanogr.

Starczak, V. R., Fuller, C. M., Butman, C. A. (1992). Effects of barite on aspects of the ecology of the polychaete Mediomastus ambiseta. Mar. Ecol. Prog. Ser. 85: 269-282

Suess, E. (1973). Interaction of organic compounds with calcium carbonate. II. Organo-carbonate association in Recent sediments. Geochim. Cosmochim. Acta 37: 2435-2447

Tagatz, M. E., Ivey, J. M., Lehman, H. K., Oglesby, J. L. (1978). Effects of a lignosulfonate-type drilling mud on development of experimental estuarine macrobenthic communities. Northeast Gulf Sci. 2: 35-42

Tagatz, M. E., Tobia, M. (1978). Effect of barite $\left(\mathrm{BaSO}_{4}\right)$ on development of estuarine communities. Estuar. coast. mar. Sci. 7: 401-407

Tanoue, E., Handa, N. (1979). Differential sorption of organic matter by various sized sediment particles in recent sediments from the Bering Sea. J Oceanogr. Soc. Japan 35: $199-208$

Tenore, K. R., Rice, D. L. (1980). Trophic factors affecting secondary production. In: Tenore, K. R., Coull, B. C. (eds.) Marine benthic dynamics. Univ, of South Carolina Press, Columbia, p. 325-334

Thistle, D. (1981). Natural physical disturbances and communities of marine soft bottoms. Mar. Ecol. Prog. Ser. 6: $223-228$

Thistle, D., Reidnauer, J. A., Findlay, R. H., Waldo, R. (1984) An experimental investigation of enhanced harpacticoid (Copepoda) abundances around isolated seagrass shoots. Oecologia 63: 295-299

Trowbridge, J. H., Geyer, W. R., Butman, C. A., Chapman, R. J. (1989). The 17-Meter Flume at the Coastal Research 
Laboratory. Part II. Flow characteristics. WHOI Tech. Rept. 89-11

Twichell, D. C., Butman, B., Lewis, R. S. (1987). Shallow structure, surficial geology, and the processes currently shaping the Bank. In: Backus, R. H. (ed.) Georges Bank. MIT Press, Cambridge, p. 31-37

VanBlaricom, G. R. (1982). Experimental analyses of structural regulation in a marine sand community exposed to oceanic swell. Ecol. Monogr. 52: 283-305

Vestal, J. R., White, D. C. (1989). Lipid analysis in microbial ecology. Bioscience 39: 535-541

Wainright, S. (1987). Stimulation of heterotrophic microplankton production by resuspended marine sediments. Science 238: 1710-1712

Watling, L. (1988). Small-scale features of marine sediments and their importance to the study of deposit-feeding. Mar. Ecol. Prog. Ser. 47: 135-144

Weise, W., Rheinheimer, G. (1978). Scanning electron microscopy and epifluorescence investigation of bacterial colonization of marine sand sediments. Microb. Ecol. 4: $175-188$

Weiler, R. R., Mills, A. A. (1965). Surface properties and pore structure of marine sediments. Deep Sea Res. 12: $511-529$

This article was presented by S. Y. Newell, Sapelo Island, Georgia, USA
Wilson, D. P., (1952). The influence of the nature of the substratum on the metamorphosis of larvae of marine animals, especially the larvae of Ophelia bicornis Savigny. Ann. Inst. Oceanogr. (Monaco) 27: 49-156

Wilson, D. P. (1953a). The settlement of Ophelia bicornis Savigny larvae, the 1951 experiments. J. mar. biol. Ass. U.K. $31: 413-438$

Wilson, D. P. (1953b). The settlement of Ophelia bicornis Savigny larvae, the 1952 experiments. J. mar. biol. Ass. U.K. 32: 209-233

Woodin, S. A. (1981). Disturbance and community structure in a shallow water sand flat. Ecology 62: 1052-1066

Yamamoto, N., Lopez, G. (1985). Bacterial abundance in relation to surface area and organic content of marine sediments. J. exp. mar. Biol. Ecol. 90: 209-220

Yingst, J. Y., Rhoads, D. C. (1980). Role of bioturbation in enhancement of bacterial growth rates in marine sediments. In: Tenore, K. R., Coull, B. C. (eds.) Marine benthic dynamics. Univ, of South Carolina Press, Columbia, p. $407-422$

Zar, J. H. (1974). Biostatistical analysis. Prentice Hall, Inc., Englewood Cliffs

Zobeli, C. E. (1938). Studies on the bacteria flora of marine bottom sediments. J. sedim. Petrol. 8: 10-18

Manuscript first received: April 3, 1992

Revised version accepted: October 16, 1992 